\title{
EFEKTIFITAS PEDOMAN PENDOKUMENTASIAN DIAGNOSA DAN INTERVENSI KEPERAWATAN BERBASIS ANDROID TERHADAP PENINGKATAN MUTU DOKUMENTASI KEPERAWATAN DI RUANG RAWAT INAP
}

\author{
Arif Puji Atmanto ${ }^{1}$, Aggorowati ${ }^{2}$, Muhammad Rofii ${ }^{2}$ \\ ${ }^{1}$ Program Studi Magister Keperawatan, Fakultas Kedokteran, Universitas Diponegoro \\ ${ }^{2}$ Staf Pengajar Prodi Magister Keperawatan, Fakultas Kedokteran, Universitas Diponegoro \\ Email : ariefpuji58@gmail.com
}

\begin{abstract}
ABSTRAK
Berbagai penelitian menunjukkan bahwa penulisan dokumentasi asuhan keperawatan di fasilitas kesehatan khususnya rumah sakit belum optimal. Hal ini disebabkan oleh faktorfaktor seperti perawat yang lebih suka berinteraksi langsung dengan pasien, rendahnya pemahaman tentang menulis dokumentasi dan mencatat asuhan keperawatan dirasakan membebani sehingga diperlukan pedoman praktis dan mudah diinstal dan digunakan pada smartphone sehingga perawat mudah menerapkan dan hemat waktu dalam pendokumentasian. Penelitian ini bertujuan untuk mengetahui efektivitas pedoman pendokumentasian diagnosa dan intervensi keperawatan berbasis android terhadap peningkatan mutu dokumentasi diagnosis dan intervensi keperawatan. Desain penelitian ini adalah quasi experiment dengan pre-post test dengan kelompok kontrol. Populasi dalam penelitian ini adalah 161 perawat di ruang rawat inap Rumah Sakit SM. Sampel diambil dengan teknik purposive sampling 35 perawat di ruang rawat inap kelas III dan untuk evaluasi menggunakan sampel dokumentasi asuhan keperawatan. Hasil penelitian pada kelompok intervensi menunjukkan peningkatan mutu dokumentasi diagnosa dan intervensi keperawatan, sebelum 31,4\% dan setelah 97,1\%; sedangkan pada kelompok kontrol menunjukkan penurunan mutu dokumentasi, sebelum $45,7 \%$ dan setelah $11,4 \%$. Pedoman pendokumentasikan diagnosa dan intervensi keperawatan berbasis android efektif meningkatkan mutu dokumentasi diagnosa dan intervensi keperawatan dari ratarata: 1,31 hingga 1,97 dengan nilai $p$-value $=0,000$, ini berarti pedoman pendokumentasikan diagnosa dan intervensi keperawatan berbasis android efektif meningkatkan mutu dokumentasi diagnosa dan intervensi keperawatan.
\end{abstract}

Kata kunci: Pedoman dokumentasi; Asuhan keperawatan; Mutu; Aplikasi

\begin{abstract}
Various research shows that the writing of nursing care documentation in health facilities especially hospitals has not been optimal. This is caused by factors such as nurses preferring to interact with patients, the low understanding about writing documentation and recording nursing care is felt to be burdensome so that a practical and easy-to-use guideline is needed and installed on a smartphone so nurses easily apply and save time in documentation. This study aims to determine the effectiveness of guidelines for documenting diagnoses and interventions based on android nursing on improving the quality of documentation of diagnoses and nursing interventions. The design of this study was quasi-experiment with pre-post test with the controlled group. The populations in the
\end{abstract}


study were 161 nurses in SM Hospital's inpatient room. Samples were taken by purposive sampling technique, 35 nurses in class III inpatient rooms and for evaluation using nursing care documentation samples. The results of the study in the intervention group showed increased quality documentation of diagnoses and nursing interventions, before $31.4 \%$ and after 97.1\%; whereas in the control group showed decreased quality of the documentation, before $45.7 \%$ and after $11.4 \%$. Guidelines for documenting diagnoses and nursing interventions based on android effectively improve the quality of documentation of nursing diagnoses and interventions from a mean: 1.31 to 1.97 with a p-value of 0,000, this means guidelines for documenting diagnoses and nursing interventions based on android effectively improve the quality of documentation of diagnoses and nursing interventions.

Keywords: Documentation guidelines; Nursing care; Quality; Application 


\section{PENDAHULUAN}

Perkembangan pengetahuan dan teknologi membuat orang berpikir lebih kritis, termasuk dalam penggunaan layanan kesehatan, oleh karena itu perawat sebagai salah satu petugas kesehatan diwajibkan untuk melakukan dokumentasi yang baik tentang asuhan keperawatan agar ketika ada masalah yang muncul antara pasien dan perawat, dokumentasi dapat digunakan sebagai bukti otentik yang dapat melindungi perawat dan pasien. Menulis dokumentasi yang akurat dan lengkap memudahkan perawat untuk mengidentifikasi masalah sehingga mereka dapat memberikan intervensi yang sesuai dengan masalah yang dihadapi oleh pasien dan secara tidak langsung akan meningkatkan mutu layanan perawatan. Menurut Depkes RI, salah satu indikator mutu dokumentasi asuhan keperawatan dapat dilihat dari kelengkapan dokumentasi keperawatan yang dilakukan oleh perawat. Menulis dokumentasi keperawatan yang tidak lengkap dan tidak akurat dapat mengurangi mutu layanan keperawatan. Menulis dokumentasi keperawatan yang tidak sesuai dengan standar akan menyebabkan kesalahan diagnosis dan pelaksanaan tindakan yang tidak tepat (Nursalam, 2011). Ketidaklengkapan dokumen dan ketidakpatuhan dengan standar yang ditentukan akan membuat sulit untuk membuktikan bahwa tindakan keperawatan telah dilakukan dengan benar (Hidayat, 2004).

Penelitian tentang kelengkapan dokumentasi asuhan keperawatan: penelitian Siswanto menunjukkan dokumentasi kelengkapan diagnosis keperawatan 85\%, perencanaan $74 \%$, penelitian Sugiati menunjukkan dokumentasi diagnosis keperawatan tidak lengkap $12,6 \%$, rencana keperawatan $28 \%$ dari 90 rekam medis, penelitian Wahyudi dari 20 format dokumentasi perawatan diambil sebagai sampel, dokumentasi tidak lengkap dari formulasi diagnosis keperawatan 42,\%, perencanaan $79 \%$, penelitian Retyaningsih diperoleh hasil bahwa perawat mendokumentasikan tetapi tidak ada formulasi diagnosis keperawatan aktual atau potensial sebesar 51,0\%, intervensi tidak diatur dalam urutan prioritas sebanyak 95,3\% (Siswanto, 2013; Sugiati, 2015; Wahyudi, 2015; Retyaningsih, 2013). Penelitian Mangole menemukan bahwa dari 100 dokumen asuhan keperawatan terdapat 10 diagnosa keperawatan tidak lengkap, 10 dokumen tidak sesuai dengan masalah, etiologi, tanda dan gejala (PES) dan tidak diisi sepenuhnya, sebanyak 10 lembar perencanaan juga tidak lengkap (Mangole, 2015).

Berdasar penulisan dokumentasi asuhan keperawatan di sebagian besar fasilitas kesehatan, terutama rumah sakit, belum ditulis secara lengkap. Hal ini disebabkan oleh beberapa faktor seperti rendahnya pemahaman perawat tentang penulisan dokumentasi dan pekerjaan pencatatan asuhan keperawatan dirasa cukup memberatkan (Personal, 2009). Perawat juga merasa bahwa menulis dokumentasi membutuhkan banyak energi, waktu dan pikiran; intervensi langsung kepada pasien lebih penting daripada dokumentasi (Nurjanah, 2013). Perawat beralasan tidak menyadari pentingnya dokumentasi standar karena perawat lebih banyak melakukan kegiatan di luar tanggung jawab perawat (kerja koordinasi dan pendelegasian wewenang) sehingga menambah beban kerja perawat, sistem dokumentasi yang sulit dan membutuhkan banyak waktu, dan tidak semua kemampuan dan pengetahuan perawat adalah sama dalam menulis dokumentasi sesuai dengan standar (Aswar, 2014).

Berdasarkan hasil survei rekam medis di Rumah Sakit SM yang dilakukan oleh peneliti pada November 2018 diperoleh data pada Agustus 2018 terdapat 
$28 \%$ (254) dari 1.212 rekam medis, 43 September (428) dari 996 dokumen dan pada Oktober $40 \%$ (394) ) dari 985 dokumen catatan medis berisi dokumentasi perawatan yang tidak lengkap. Hasil penilaian awal dari 20 sampel rekam medis pasien pada bulan Desember 2018 diperoleh data: 11 rekam medis yang berisi dokumentasi asuhan keperawatan tidak lengkap; 45\% dokumentasi diagnosis keperawatan tidak sesuai dengan respons pasien, belum ditulis dengan baik dan tidak sesuai dengan NANDA (North American Nursing Diagnosis Association); $54 \%$ dari dokumen perencanaan tidak sesuai dengan masalah, belum ditulis dengan baik, belum sesuai dengan NIC (Nursing Intervenstion Classification) dan NOC (Nursing Outcome Clasification). Hasil wawancara dengan lima perawat yang bekerja di ruang rawat inap Rumah Sakit SM menyatakan bahwa mereka merasa tidak cukup waktu untuk mengisi dokumentasi; ada pedoman pendokumentasian tetapi ditetapkan secara tertulis dan tidak dalam sepuluh penyakit teratas, tidak semua diagnosis dan intervensi keperawatan dimasukkan; juga pedoman yang kurang fleksibel karena belum berbentuk aplikasi.

Perawat dalam mengatasi masalah di atas memerlukan pedoman dokumentasi atau sistem informasi yang dapat mengakomodasi data yang dibutuhkan secara sistematis dan efisien, salah satunya adalah pedoman pendokumentasian diagnosa dan intervensi berbasis android yang berisi data diagnosa dan intervensi keperawatan yang merujuk pada sepuluh kasus besar penyakit di Rumah Sakit SM, dan berdasar NANDA (North American Nursing Diagnosis Association), Depkes RI, SDKI (Standar Diagnosa Keperawatan Indonesia), Q-DIO (Quality of Nursing Diagnosis Intervention and Outcomes) dan NIC (Nursing Intervention Classification), serta NOC (Nursing Outcome Classification). Penerapan pedoman dokumentasi berbasis android merupakan upaya untuk meningkatkan mutu dan kelengkapan dokumentasi asuhan keperawatan, terutama dokumentasi diagnosa dan intervensi keperawatan. Aplikasi ini diharapkan dapat digunakan sebagai panduan oleh perawat dalam mendokumentasikan asuhan keperawatan sehingga dapat menghemat waktu, lebih praktis dan mudah diterapkan dan dapat membantu dokumentasi kearah standar. Aplikasi ini meningkatkan akurasi dan efisiensi penulisan dokumentasi keperawatan, memfasilitasi komunikasi antara perawat ketika merawat pasien, dan mencegah kesalahan pengobatan (Efendi, 2017).

Layanan asuhan keperawatan yang baik harus terstruktur dan berkelanjutan, ini akan memudahkan perawat dalam menangani masalah pasien. Pemberian asuhan keperawatan terkadang tidak akurat karena kelalaian perawat sehingga dibutuhkan sebuah pedoman yang dapat memuat data-data asuhan keperawatan yang mudah diakses dan digunakan. Aplikasi ini berguna untuk membantu perawat melakukan tugas secara efektif dan efisien karena aplikasi ini dilengkapi dengan data asuhan keperawatan berbasis NANDA, dan, NIC-NOC (Segara, 2013).

\section{METODE PENELITIAN}

Desain penelitian ini adalah eksperimen semu dengan kelompok kontrol pre-post test. Penelitian ini dilakukan dari tanggal 16 Mei hingga 4 Juli 2019 di Ruang Rawat Inap Kelas III Rumah Sakit SM untuk kelompok intervensi dan Layanan Rawat Inap Kelas III di Rumah Sakit BW untuk kelompok kontrol. Populasi dalam penelitian ini adalah 161 perawat di Ruang Rawat Inap Rumah Sakit SM. Sampel diambil dengan teknik purposive sampling, 35 responden 
kelompok intervensi dan 35 responden kelompok kontrol. Semua responden yang terdaftar dalam penelitian ini secara sukarela setuju untuk berpartisipasi dan memberikan persetujuan tertulis setelah mendapat penjelasan tentang penelitian. Instrumen adalah lembar untuk melihat karakteristik responden, kuesioner $Q-D I O$ untuk menilai mutu dokumentasi asuhan keperawatan yang memiliki 40 pertanyaan dan P-Askep aplikasi berbasis android memiliki pedoman untuk mendokumentasikan diagnosis dan intervensi keperawatan. Sebelum menerapkan intervensi, penelitian mengadakan pre-test menggunakan kuesioner $Q-D I O$ untuk dua kelompok. Kemudian dilanjutkan pelatihan 1 hari, 3 hari bantuan untuk implementasi, dan 1 bulan implementasi independen oleh perawat. Data dibandingkan dengan menggunakan uji berpasangan Wilcoxon. Semua analisis statistik dilakukan dengan menggunakan SPSS untuk Windows.

\section{HASIL DAN PEMBAHASAN}

\section{Hasil}

Tabel 1. Karakteristik Responden

\begin{tabular}{|c|c|c|c|}
\hline \multirow[b]{2}{*}{ Variabel } & \multicolumn{2}{|c|}{ Kelompok } & \multirow[b]{2}{*}{$\begin{array}{c}p \text {-value } \\
\left(X^{2}\right)\end{array}$} \\
\hline & $\begin{array}{c}\text { Intervensi } \\
(\mathbf{N}=35) \\
\mathbf{n}(\%)\end{array}$ & $\begin{array}{c}\text { Kontrol } \\
(\mathbf{N}=35) \\
\mathbf{n}(\%)\end{array}$ & \\
\hline \multicolumn{4}{|l|}{ Usia } \\
\hline 20-35 tahun & $19(54,3)$ & $26(74,3)$ & 0,067 \\
\hline $36 \mathrm{ke}$ atas & $16(45,7)$ & $9(25,7)$ & \\
\hline \multicolumn{4}{|l|}{ Jenis Kelamin } \\
\hline Laki-laki & $6(17,1)$ & $4(11,4)$ & 0,367 \\
\hline Perempuan & $29(82,9)$ & $31(88,6)$ & \\
\hline \multicolumn{4}{|l|}{ Pendidikan Terakhir } \\
\hline S1 & $8(22,9)$ & $4(11,4)$ & 0,171 \\
\hline D3 & $27(77,1)$ & $31(88,6)$ & \\
\hline \multicolumn{4}{|l|}{ Status Perkawinan } \\
\hline Menikah & $31(88,6)$ & $20(57,1)$ & 0,039 \\
\hline Belum Menikah & $4(11,4)$ & $15(42,9)$ & \\
\hline \multicolumn{4}{|l|}{ Masa Kerja } \\
\hline $1-9$ tahun & $17(48,6)$ & $20(57,1)$ & 0,316 \\
\hline 10 tahun ke atas & $18(51,4)$ & $15(42,9)$ & \\
\hline
\end{tabular}

Dari tabel di atas dapat diketahui bahwa ada perbedaan mayoritas karakteristik responden (heterogen) kecuali untuk karakteristik status perkawinan yang tidak ada perbedaan pada 2 kelompok atau homogen.

Tabel 2. Mutu dokumentasi diagnosa dan intervensi keperawatan

\begin{tabular}{lcccc}
\hline \multirow{2}{*}{ Mutu } & \multicolumn{2}{c}{ Intervensi } & \multicolumn{2}{c}{ Kontrol } \\
& Pre Test & Post Test & Pre Test & Post Test \\
\hline Baik & $11(31.4 \%)$ & $34(97.1 \%)$ & $16(45.7 \%)$ & $4(11.4 \%)$ \\
Kurang Baik & $24(68.6 \%)$ & $1(2.9 \%)$ & $19(54.3 \%)$ & $31(88.6 \%)$ \\
\hline Amount & $35(100 \%)$ & $35(100 \%)$ & $35(100 \%)$ & $35(100 \%)$ \\
\hline
\end{tabular}


Tabel di atas menunjukkan pada kelompok intervensi bahwa mutu dokumentasi diagnosa dan intervensi keperawatan yang baik sebelum intervensi $31,4 \%$ dan setelah intervensi naik menjadi $97,1 \%$, sedangkan pada kelompok kontrol mutu dokumentasi diagnosis dan intervensi keperawatan baik dari 45,7\% sebelum intervensi menurun menjadi $11,4 \%$ setelah intervensi.

Tabel 3. Mutu dokumentasi diagnosa dan intervensi keperawatan sebelum dan sesudah intervensi dalam Kelompok Intervensi dan Kontrol

\begin{tabular}{lccccc}
\multirow{2}{*}{$\begin{array}{l}\text { Mutu dokumentasi diagnosa } \\
\text { dan intervensi keperawatan }\end{array}$} & \multicolumn{2}{c}{ Intervensi } & \multicolumn{2}{c}{ Kontrol } & \multirow{2}{*}{$\boldsymbol{p}$-value } \\
\cline { 2 - 5 } & Mean & SD & Mean & SD & \\
\hline Pre-test & 1,31 & 0,471 & 1,46 & 0,505 & $0,223^{*}$ \\
Post-test & 1,97 & 0,169 & 1,11 & 0,323 & $0,000^{*}$ \\
\hline
\end{tabular}

Pada tabel di atas menunjukkan bahwa mutu dokumentasi sebelum intervensi pada kelompok intervensi dan kelompok kontrol dengan nilai rata-rata 1,31 $\pm 0,471$ dan pada kelompok kontrol dengan rata-rata 1,46 $\pm 0,505$, p-nilai 0,223 ( $p$-value $>0,05$ ) diperoleh. artinya tidak ada perbedaan antara 2 kelompok sebelum intervensi. Sedangkan setelah intervensi pada kelompok intervensi nilai rata-rata adalah $1,97 \pm 0,169$ dan kelompok kontrol dengan rata-rata $1,11 \pm 0,323$, $p$-value 0,000 ( $p$-value $<0,05)$, yang berarti bahwa terdapat perbedaan antara 2 kelompok setelah intervensi.

Tabel 4. Efektivitas pedoman pendokumentasian diagnosa dan intervensi keperawatan berbasis android untuk meningkatkan mutu dokumentasi diagnosa dan intervensi keperawatan

\begin{tabular}{lcccc}
\hline & \multicolumn{2}{c}{ Intervention } & \multicolumn{2}{c}{ Control } \\
\cline { 2 - 5 } & Mean & SD & Mean & SD \\
\hline Pre-test & 1,31 & 0,471 & 1,46 & 0,505 \\
Post-test & 1,97 & 0,169 & 1,11 & 0,323 \\
p-value & \multicolumn{2}{c}{$0,000^{* *}$} & \multicolumn{2}{c}{$0,005^{* *}$} \\
\hline
\end{tabular}

Tabel di atas menunjukkan hasil uji Wilcoxon setelah dan sebelum intervensi kepada kelompok intervensi dan kelompok kontrol, hasil yang diperoleh ( $p$-value $=0,000<0,05)$, yang berarti ada perbedaan pada kelompok intervensi sebelum dan sesudah intervensi diberikan, ini dapat diartikan sebagai panduan dokumentasi diagnosa keperawatan berbasis Android dan intervensi yang secara efektif meningkatkan mutu dokumentasi diagnosa dan intervensi keperawatan.

\section{PEMBAHASAN}

Hasil penelitian menunjukkan bahwa mutu dokumentasi diagnosa dan intervensi keperawatan sebelum intervensi pada kelompok intervensi dengan ratarata 1,31 $\pm 0,471$ dan pada kelompok kontrol dengan rata-rata 1,46 $\pm 0,505$ dengan nilai $\mathrm{p} 0,223$ ( $\mathrm{p}$ - nilai> 0,05 ) yang berarti ada perbedaan mutu dokumentasi antara kedua kelompok sebelum intervensi. Sedangkan setelah intervensi pada kelompok intervensi, nilai rata-rata adalah $1,97 \pm 0,169$ dan kelompok kontrol adalah $1,11 \pm 0,323$ dengan nilai $p$-value $=0,000$ (nilai $p<0,05$ ), 
yang berarti bahwa terdapat perbedaan mutu dokumentasi. antara 2 kelompok setelah intervensi.

Berdasar hasil penelitian di atas menunjukkan bahwa keadaan awal sebelum intervensi P-Askep adalah bahwa sebagian besar mutu dokumentasi keperawatan berada dalam kategori yang tidak baik dari kelompok intervensi dan kelompok kontrol, ini seperti penelitian sebelumnya yang dilakukan oleh Sulistiyaningsih hanya 48,2\% dari dokumentasi yang diisi asuhan keperawatan, ini karena SOP asuhan keperawatan terlalu banyak, belum sederhana dan masih menggunakan teknologi manual dan belum menggunakan teknologi digital (Sulistiyaningsih, 2018). Studi lain yang dilakukan oleh Suhendri dan Malini menyebutkan sebanyak 65,6\% dokumentasi yang dilakukan oleh perawat tidak lengkap, salah satu alasannya adalah karena sistem pencatatan sulit untuk dinilai, sehingga perawat hanya melakukan sesuai dengan kemampuan mereka tanpa memenuhi standar yang ada (Suhendri, 2005). Penelitian Mulyaningsih menyatakan bahwa dokumentasi keperawatan sering ditemukan tidak lengkap dan tidak dapat dibenarkan dan bahkan cenderung diabaikan karena dalam menyelesaikan dokumentasi asuhan keperawatan memerlukan banyak waktu untuk menulis sehingga untuk mengambil waktu perawat dalam asuhan keperawatan (Mulyaningsih, 2011 ).

Hasil penelitian di atas menunjukkan hasil uji Wilcoxon setelah dan sebelum intervensi diberikan kepada kelompok intervensi dan kelompok kontrol, hasil yang diperoleh ( $p$-value $<0,05$ ), yang berarti terdapat perbedaan pada kelompok intervensi sebelum dan setelah intervensi diberikan, ini dapat diartikan bahwa aplikasi dokumentasi keperawatan berbasis Android dan pedoman intervensi keperawatan efektif dalam meningkatkan mutu dokumentasi diagnosa dan intervensi keperawatan. Peningkatan mutu dokumentasi tentang diagnosa dan intervensi keperawatan adalah karena intervensi P-Askep memiliki beberapa keunggulan termasuk pedoman ini memanfaatkan teknologi dengan merangkum pedoman untuk mendokumentasikan asuhan keperawatan berbasis 10 kasus penyakit terbaik Rumah Sakit SM pada tahun 2018 yang mengacu pada NANDA, SDKI, NIC-NOC, dan Q-DIO ke dalam aplikasi android atau smartphone di mana setiap perawat sudah memilikinya dan cukup mengunduhnya di play store / google drive sehingga perawat dapat dengan mudah mengakses atau membuka pedoman. Hal ini sesuai dengan penelitian Dewi, pengembangan dokumentasi keperawatan elektronik berbasis teknologi informasi yang memberikan manfaat bagi perawat, antara lain: waktu dokumentasi menjadi lebih pendek, kemudahan membaca dan mengakses dokumen dan memungkinkannya sebagai alat pembelajaran (Dewi, 2010). Penelitian lain tentang penggunaan teknologi aplikasi di rumah sakit menyatakan bahwa aplikasi android dipilih sebagai panduan yang membantu perawat dalam mendokumentasikan diagnosa dan intervensi keperawatan karena aplikasi android lebih mudah diimplementasikan dan murah, ponsel dapat dibawa kemana saja berbeda dari komputer yang lebih besar dan laptop, selain penggunaan smartphone untuk keperluan mencari dan mendapatkan informasi secara efektif dan efisien di mana saja dan kapan saja selama 24 jam, berbagai informasi tersedia dalam aplikasi pada smartphone yang dapat diakses dengan mudah. Penggunaan smartphone tidak dibatasi oleh waktu dan tempat (Rahayu, 2017; Sulistiyaningsih, 2018). 
Keuntungan kedua dari aplikasi P-Askep adalah bahwa menu yang tersedia dapat meningkatkan pengetahuan perawat secara kognitif, afektif dan psikomotor. Studi lain tentang penggunaan teknologi aplikasi di rumah sakit adalah studi pengetahuan Indari tentang SOP keperawatan setelah penerapan aplikasi keperawatan meningkat $18,8 \%$ dan kesimpulan dari penelitian ini adalah aplikasi SIM keperawatan memiliki pengaruh yang signifikan terhadap pengetahuan tentang SOP keperawatan di kamar anak RSSA Malang (Indari, 2015). Aplikasi ini dapat diakses melalui play store / google drive. Aplikasi ini dibuat menarik dan mudah dipasang karena aplikasi ini hanya membutuhkan ruang / memori 3,23 MB sehingga semua perawat dapat menginstal pada smartphone mereka dan membuatnya lebih mudah bagi perawat untuk menggunakannya. Aplikasi PAskep memiliki informasi yang berisi pedoman untuk mendokumentasikan diagnosa dan intervensi keperawatan yang mengacu pada standar NANDA, NIC$N O C$, SDKI dan $Q-D I O$ dan didasarkan pada 10 kasus besar penyakit di Rumah Sakit SM. yang terjadi pada tahun 2018. Aplikasi ini terdiri dari menu: diagnosis keperawatan, tujuan, dan kriteria hasil, intervensi keperawatan dan instrumen modifikasi $Q-D I O$ yang dapat digunakan sebagai alat untuk mengevaluasi pelaksanaan dokumentasi asuhan keperawatan. Ini sesuai dengan penelitian Muller, dkk. Menyatakan bahwa mutu dokumentasi keperawatan meningkat dengan adopsi penggunaan Q-DIO (Quality of Nursing Diagnosis, Intervensi, and Outcomes). Penelitian ini mendukung penggunaan $Q-D I O$ dalam mengevaluasi dokumentasi diagnosa, intervensi dan hasil asuhan keperawatan. Perawat dalam meningkatkan mutu dokumentasi perlu dukungan melalui pendidikan untuk mengetahui langkah-langkah dalam menghubungkan diagnosis dengan intervensi, khusus untuk etiologi dan untuk mengidentifikasi hasil asuhan keperawatan. Peningkatan mutu dokumentasi membuktikan bahwa penerapan $Q-D I O$ berguna sebagai instrumen audit untuk dokumentasi keperawatan dan harus dikembangkan sebagai fitur yang terintegrasi secara elektronik (Muller, 2006).

\section{SIMPULAN DAN SARAN}

\section{Simpulan}

Penelitian ini membuktikan bahwa pedoman dokumentasi diagnosa dan intervensi keperawatan berbasis android efektif dalam meningkatkan mutu dokumentasi diagnosa dan intervensi keperawatan.

\section{Saran}

Peneliti menyarankan agar dalam penelitian selanjutnya penelitian ini dapat dijadikan sebagai data dasar untuk pengembangan penelitian bidang keperawatan berbasis teknologi informasi/ berbasis android.

\section{DAFTAR PUSTAKA}

Aswar S. (2014). Faktor-Faktor yang Mempengaruhi Efektivitas Implementasi Dokumentasi Perawatan Perawat di Instalasi Rawat Inap Bedah Rumah Sakit Andi Makkasau Parepare. Jurnal Ilmiah Diagnosis Kesehatan. Vol. 5 No. 4.

Dewi, S Candra. (2010). Pengembangan Dokumentasi Keperawatan Berbasis Teknologi Informasi. Fakultas Keperawatan. Universitas Indonesia. 
Efendi D., Sari D. (2017). Aplikasi Mobile-Health sebagai Upaya untuk Meningkatkan Mutu Layanan Keperawatan untuk Anak-anak dengan Penyakit Kronis di Pengaturan Rumah Sakit Rumah. Jurnal Keperawatan. Volume 20.

Hidayat A.A. (2004). Pengantar Konsep Dasar Keperawatan. Salemba Medika. Jakarta.

Indari. (2015). Pengaruh Aplikasi SIM Perawat Anak Berbasis Teknologi Terhadap Pengetahuan tentang SOP di Ruang Anak RSAA Malang. Jurnal Kesehatan Hesti Wira Sakti. Vol. 3.

Mangole, J E. Hubungan antara Perilaku Perawat dan Dokumentasi Perawatan Perawat di Rumah Sakit Umum Pusat Cardiovaskular dan Brain Center Prof. Dr. R. D. Kandou Manado. Jurnal Keperawatan UNSRAT. Vol 3 (2): $1-9$.

Muller, dan sebagainya. (2006). Evaluasi Dokumentasi Sebelum dan Setelah Pendidikan Staf dalam Diagnosis Keperawatan, Intervensi, dan Hasil dan Implikasi Catatan Kesehatan Elektronik. International Journal of Nursing Terminology and Clssifications. Volume 17. No. 1.

Mulyaningsih. (2011). Meningkatkan Mutu Dokumentasi Keperawatan dengan

Sistem Informasi Keperawatan Berbasis Komputer. Jurnal Ilmu dan Teknologi Kesehatan. Vol. 2 No. 1.

Nurjanah S. (2013). Tinjauan Umum Dokumentasi Lengkap Perawatan Perawat di Rumah Sakit Kabupaten Pandanaran Boyolali. Karangan. UMS Surakarta.

Nursalam. (2011). Proses dan Dokumentasi Keperawatan. Konsep dan Isu Praktek

2. Salemba Medika. Jakarta. 2011

Pribadi. (2009). Analisis Pengaruh Faktor Pengetahuan, Motivasi, dan Persepsi Perawat terhadap Pengawasan Kepala Ruang pada Implementasi Dokumentasi Perawatan Perawat di Rumah Sakit Kabupaten Kelet di Provinsi Jawa Tengah di Jepara. Tesis.

Rahayu S. (2017). Pengaruh Penggunaan Smartphone pada Pemenuhan Informasi Program Studi Sarjana Ilmu Perpustakaan UIN Ar-raniry. Karangan.

Retyaningsih. (2013). Hubungan antara Karakteristik Perawat, Motivasi, dan Pengawasan dengan Dokumentasi Mutu Proses Perawatan. Manajemen Keperawatan Jurnal. (2): 107-14.

Segara T. (2013). Merancang dan Membangun Aplikasi Perawat Berbasis Android. Jurnal Unsoed.

Siswanto L M, Hariyanti R T, Sukihananto S. (2013). Faktor-Faktor Terkait Kelengkapan Dokumentasi Asuhan Keperawatan. Jurnal Keperawatan Indonesia. Vol 16 (2): 77-84.

Sugiyati, Sri. (2015). Hubungan Pengetahuan Perawat dalam Dokumentasi Keperawatan dengan Implementasinya di Rawat Inap Rumah Sakit Kendal. Jurnal Keperawatan Fikkes. Vol 8 (2): 109-125.

Sulistiyaningsih. (2018). Pengaruh Sistem Informasi dalam Perawatan Perawat pada Kepatuhan Perawat dalam Melaksanakan Halusinasi SOP Perawatan Perawat di Rumah Sakit Kota Surakarta. Tesis. Undip.

Suhendri \& Malini. (2005). Hubungan antara Pengawasan Perawat dan Kelengkapan Dokumentasi Proses Keperawatan di Ruang Rawat Inap P3SN Rumah Sakit Bukittinggi. PSIK FK Unand. Padang. 
Wahyudi U. (2015). Pengaruh Penggunaan Format Dokumentasi Keperawatan Berbasis Daftar Periksa pada Mutu Dokumentasi Perawatan Perawat di Ruang Rawat Inap Rumah Sakit Regional KRT. Setjonegoro Wonosobo. Tesis. Undip. 